\title{
PERSPECTIVE
}

\section{Immunopathology of uveitis}

\author{
Chi-Chao Chan, Qian Li
}

Using conventional histological (light and electron microscopic examinations), immunohistological (immunofluorescent and immunoperoxidase), and molecular histological (in situ hybridisation and polymerase chain reaction (PCR) in situ hybridisation) techniques, the immunopathology of uveitis has been studied using inflamed ocular tissue. ${ }^{1-4}$ The findings usually provide helpful information in the diagnosis and therapy of uveitis. The immunopathology of uveitis allows the visualisation of the morphological interaction in the eye at the time the specimen is obtained. This information also helps in the understanding of the immunopathogenesis of ocular inflammation.

Three main aspects of pathological examinations are analysed. Firstly, the morphology of the ocular specimen illustrates the lesions and specific localisations within the eye. These include inflammatory exudate in the anterior chamber, known as hypopyon, commonly located at the inferior angle, inflammatory cellular infiltration in the cornea (keratitis), the uvea (focal or diffuse iritis, cyclitis, iridocyclitis, choroiditis), the retina (retinitis), the vitreous (vitritis or abscess), the sclera (scleritis), and inflammation surrounding the lens or its remnants. The following terms indicate certain pathological findings in the eye. Endophthalmitis occurs when ocular inflammation is confined to three or more tissues inside the eye. Panophthalmitis, on the other hand, indicates that ocular inflammation involves all layers of the eye including the sclera. Anterior uveitis is ocular inflammation in the cornea, the iris, and the ciliary body. Posterior uveitis is ocular inflammation in the choroid, the retina, and the vitreous. Panuveitis is ocular inflammation in both anterior and posterior segments of the eye.

Secondly, agents that induce inflammation. Biological, chemical, or physical stimuli can induce ocular inflammation. Various infectious micro-organisms including bacteria, viruses, fungi, and parasites are capable of triggering different degrees of inflammatory response. Several ocular proteins, such as retinal soluble antigen $(\mathrm{S}-\mathrm{Ag}),{ }^{5}$ interphotoreceptor retinoid binding protein (IRBP), ${ }^{6}$ and uveal melanin associated proteins, ${ }^{7}$ are autoantigens inside the eye. These potent antigens are known not only to induce ocular inflammation in various animal models, ${ }^{5-7}$ but also may be involved in human uveitides based on clinical studies. ${ }^{8-10}$ Cellular responses to S-Ag, IRBP, and their peptides have been reported in patients with uveitis. ${ }^{11-13}$ Antiretinal autoantibodies have been shown in the sera of uveitic patients. ${ }^{14}{ }^{15}$ Some investigators have considered that sympathetic ophthalmia and Vogt-Koyanagi-Harada $(\mathrm{VKH})$ syndrome reflect autoimmunity against choroidal melanocytes. ${ }^{16-18}$ Recently, two peptides derived from the human S-Ag have been found to bind efficiently to HLAA29, the predisposing allele for birdshot retinopathy. ${ }^{19}$ This finding demonstrates the implication of $\mathrm{T}$ cell epitopes from retinal autoantigens in birdshot retinopathy. Trauma and foreign bodies can elicit an inflammatory reaction surrounding the wound and foreign material. Tumours may also initiate an inflammatory response.

Thirdly, the inflammatory process involves two types of cellular components-the infiltrating inflammatory cells and the ocular resident cells. The types and subtypes of inflammatory cells are easily identified by routine histology and immunohistochemical stains. ${ }^{34}$ These cells release numerous lymphokines, cytokines, immunoglobulins, growth factors, and inflammatory mediators, which can be identified by immunohistochemistry. ${ }^{3}$ The messenger RNAs of many cytokines and growth factors can be detected by molecular histological techniques. ${ }^{12}$ The ocular resident cells may undergo oedema, damage, necrosis, or proliferation. They also respond by releasing cytokines, growth factors, and altering cellular markers including major histocompatibility complex molecules (MHC class I and II), and adhesion molecules.

On examining a specimen, consideration of the clinical presentation of the disease is extremely important. The inflammatory response depends on the host condition. Immunocompromised patients generate less inflammatory reaction than immunocompetent patients. Patients with diabetes mellitus or carcinoma may produce a different inflammatory response. Ocular inflammation can be altered by medical treatment, especially immunosuppressive medication or radiation. The genetic background and family history of the patient will also help clarify the immunopathology of uveitis.

Because the inflammatory reaction involves such a dynamic process, there is only a short time to view the disease. The pathology is based on this particular picture for the interpretation of the entire inflammatory process. The situation is like being asked to tell a cartoon story from looking at one drawing. Thus, it is necessary to survey the ophthalmic microenvironment for changes in various ocular components and to properly appreciate how these changes influence each other. ${ }^{20}{ }^{21}$ Many clinical specimens are obtained from end stage disease, and so they may be of little use for the treatment of individual cases.

\section{Techniques}

Routine histology for ocular tissues may require additional processing steps other than those used for other tissues in the body. ${ }^{20}$ The clearing and embedding agents may be different and need to be handled extra carefully. The histotechnician should have a working knowledge of ocular anatomy to be able to follow the instructions provided by the ophthalmic pathologist. However, the methods of histological staining for ophthalmic pathology are often the same as those for other surgical specimens. Light and electron microscope studies are frequently complementary.

In general, the immunohistochemical technique for ocular tissues is similar to that for other tissues. ${ }^{3}$ The art of immunohistochemistry allows for the union of immunology with microscopy, a specialised application of the 
antigen-antibody reaction on the tissue section. A specific antibody is needed and the specimen must be prepared in such a way as to preserve the reactivity of the antigen. Cryostat sections may retain tissue antigenicity better than paraffin sections but they may show poor morphology. Immunofluorescence, immunoperoxidase, avidin-biotin complexes, and immunogold have been commonly used as immunolabelling methods. Except for the colloidal gold methods for electron microscopy, immunohistochemical staining for light microscopy depends upon enzymesubstrate reactions that will convert colourless chromogens into visible, coloured end products.

In situ hybridisation, the localisation of specific messenger RNA (mRNA) or DNA in tissues and cells using nucleic acid probes, has become an increasingly valuable technique. This method is able to detect genes of foreign pathogenic $\mathrm{DNA}^{2}$ and to identify a specific cytokine at the transcriptional level. ${ }^{22}$ There are many protocols for in situ hybridisation. ${ }^{123}$ Each protocol includes preparation of the tissue section on a coated slide, tissue fixation and pretreatment, labelling of a specific probe, hybridisation, post-hybridisation washing, and signal visualisation by immunohistochemistry or autoradiography. Proteolytic enzymes allow better penetration of the probe into paraffin fixed tissue. The labelling of non-radioactive probes with biotin, digoxigenin, or fluorescence can avoid the use of hazardous radioactive reagents, increase the resolution, and shorten the exposure time needed for detection of a signal. The sensitivity of non-radioactive probes has been improved greatly and is now comparable with radioactive probes.

\section{Classification}

The inflammatory process is divided into acute and chronic inflammation. ${ }^{24}$ In acute inflammation, the main infiltrating cells are polymorphonuclear neutrophils and macrophages accompanying by oedema, vascular dilatation, and congestion. Tissue damage can result in necrosis. In contrast, the main infiltrating cells in chronic inflammation are lymphocytes and macrophages with exudate, vascular congestion, and obstruction. Tissue damage can result in necrosis and/or cellular proliferation, such as fibrosis and gliosis.

The form of inflammation is categorised into granulomatous and non-granulomatous inflammation. ${ }^{24}$ The epithelioid and giant cells, surrounded by lymphocytes and macrophages, form the granuloma. Necrosis is associated with some granulomatous inflammation. Granulomatous inflammation can be associated with chronic or subacute inflammation. This inflammation may result from infections of tuberculosis, syphilis, leprosy, fungi, and viruses. Granulomatous inflammation may also be associated with systemic diseases such as sarcoidosis ${ }^{25}$ and rheumatoid arthritis ${ }^{26}$ and some autoimmune uveitis such as phacoanaphylaxis, ${ }^{27}$ sympathetic ophthalmia, ${ }^{28} \mathrm{VKH}$ syndrome, ${ }^{16}$ and birdshot retinochoroidopathy. ${ }^{29}$ Yet the main infiltrating cells in nongranulomatous inflammation are all kinds of leucocytes: polymorphonuclear neutrophils, eosinophils, basophils, lymphocytes, and macrophages. Non-granulomatous inflammation can be associated with either acute or chronic inflammation, which may be caused by toxic stimulus, viral infection, or unknown agents. Non-granulomatous inflammation may be associated with systemic diseases such as ankylosing spondylitis, Reiter's syndrome, Behçet's disease, multiple sclerosis, and ulcerative colitis, ${ }^{30}$ and some autoimmune uveitis such as pars planitis ${ }^{31}$ and Fuchs' iridocyclitis. ${ }^{32}$

The aetiology of inflammation is divided into infectious and non-infectious. ${ }^{24}$ Bacteria, fungi, viruses, and parasites including protozoa, helminths, and chlamydia have been reported to cause ocular inflammation. Each micro- organism elicits different kinds of responses in the host. These infectious agents must invade the body and target the eye. Once the micro-organism enters ocular tissue, an immune response is generated. In general, Gram positive and Gram negative bacteria produce an acute inflammatory response and abscess formation. Acid fast bacteria produce granulomatous inflammation and caseation necrosis. Fungi, while targeting the choroid, produce chronic granulomatous or non-granulomatous inflammation and hypersensitivity reactions. Identified by viral inclusion bodies, viruses produce chronic non-granulomatous inflammation and may cause resident cell transformation. Viruses tend to target the cornea and the retina. Dead parasites may cause an inflammatory reaction in the host. Specific stains-for example, Gram and acid fast stains for bacteria, Grocott's methenamine-silver stain for fungi, and Warthin-Starry stain for spirochaetes, are required to identify microorganisms invading the eye. Electron microscopic examination of viral particles and immunohistochemical staining for viral antigens or in situ hybridisation and PCR in situ hybridisation for viral DNAs are required to identify virus in the eye. Non-infectious inflammation can present all types of inflammatory responses - chronic or acute, and non-granulomatous or granulomatous.

\section{Infiltrating cells in uveitis}

GRANULOCYTES

All three types of granulocytes can be found in uveitis. ${ }^{21}$ Polymorphonuclear neutrophils are the hallmark of acute inflammation. ${ }^{33}$ These cells secrete several cytokines including interleukin (IL) 1 , IL-8, tumour necrosis factor $\alpha$ $(\mathrm{TNF}-\alpha)$, and defensin. In general, the cytokines released by inflammatory cells are proinflammatory except defensin, which is also an effective microbicide. ${ }^{34}{ }^{35}$ When the accumulation of neutrophils is accompanied by liquefaction and necrosis of the tissue, an abscess may form inside the eye. This is characteristic of bacterial endophthalmitis and Behçet's disease. ${ }^{30}$

Eosinophils are the most striking infiltrating cells observed in allergic reactions. ${ }^{36}$ In vernal conjunctivitis collections of eosinophils are seen in the conjunctiva and the limbus (Trantas dots).$^{37}$ Eosinophils are also associated with parasitic infections. ${ }^{36}$ Major basic protein, a secondary granule of eosinophils, plays a critical role in killing the parasite. This protein is detectable in the conjunctiva of patients with ocular onchocerciasis. ${ }^{38}$

Basophils and mast cells have similar functions that produce vasoactive and chemotactic mediators including the leukotrienes. ${ }^{39}$ These cells contain metachromatic granules which stain positively with toluidine blue. Mast cells are found in abundance in the uvea and conjunctiva. They are important in modulating the initiation of certain experimental uveitis, including experimental autoimmune uveoretinitis $^{40}$ and endotoxin induced uveitis. ${ }^{41}$ The mast cell degranulation agent can induce allergic conjunctivitis in different animal species. ${ }^{42} 43$

MACROPHAGES

In the immune response, the macrophage is an antigen presenting cell for MHC class II restricted helper $\mathrm{T}$ lymphocytes. In contrast with the granulocytes, macrophages can proliferate in tissue and synthesise numerous potent biological cytokines, growth factors, and inflammatory mediators capable of influencing inflammation. IL-1, IL-6, TNF- $\alpha$, transgenic growth factor $\beta$ (TGF- $\beta$ ), defensins, and nitric oxide are the few listed proteins that can further modulate the immune reaction. The close spatial localisation between macrophages and defensin has been illustrated in the inflamed iris. ${ }^{44}$ Macrophages are the 

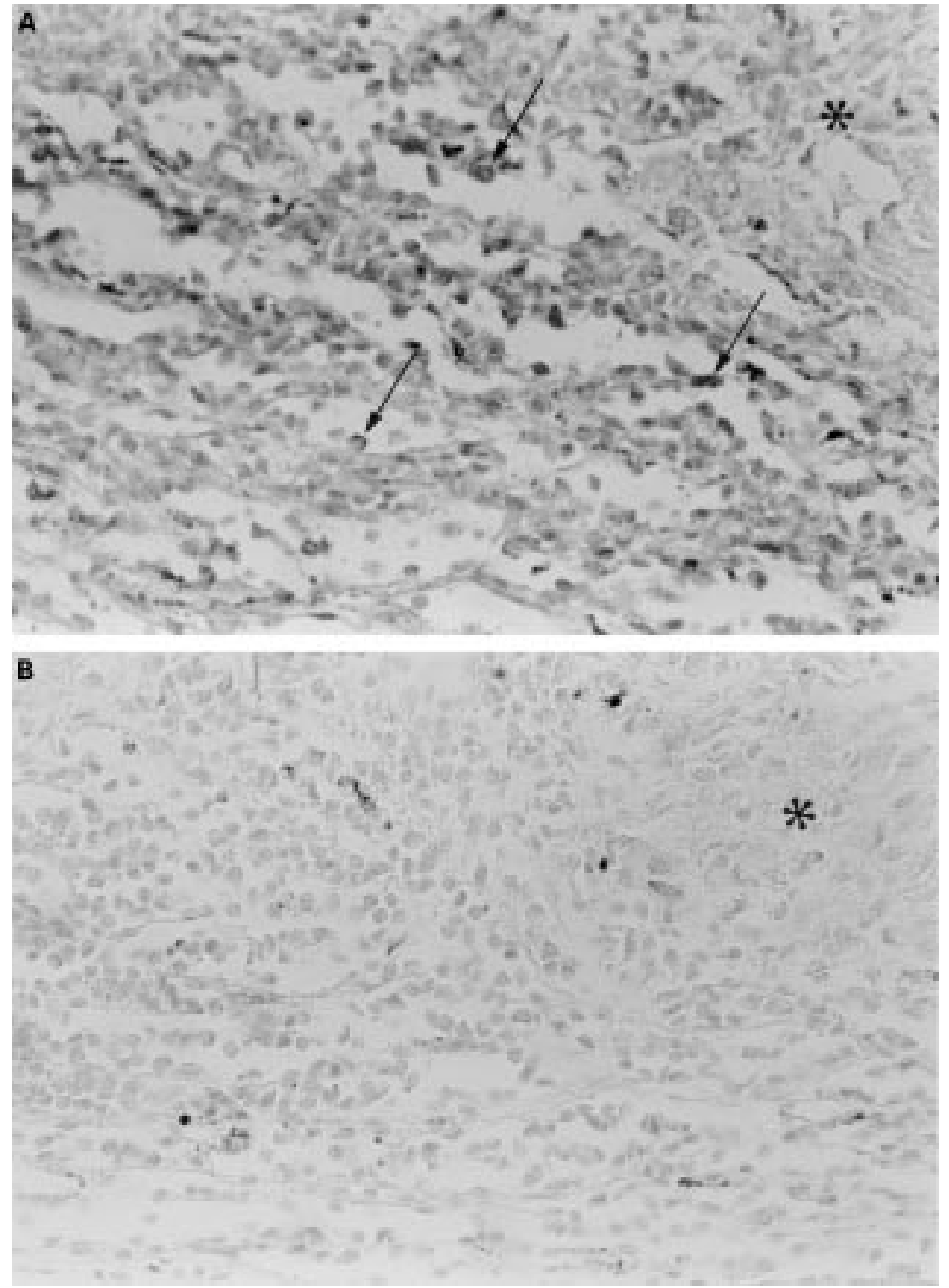

Figure 1 Microphotograph of the choroid from an eye with sympathetic ophthalmia shows positive IL-2 $m R N A$ ( $A$, arrows) and negative IL-4 $m R N A(B)$ released by the infiltrating lymphocytes. (Asterisk, granuloma; in situ hybridisation, riboprobes-dioxygenin labelling, methyl green counterstain, $\times 280$.)

major component of granulomatous inflammation including granuloma in uveitis and Dalen-Fuchs' nodules in sympathetic ophthalmia. ${ }^{45}$

Macrophages belong to the phagocyte system, ${ }^{46}$ and play an important role as effector cells for engulfing and in killing exogenous micro-organisms such as mycobacteria and viruses. Macrophages are the mobile monocytes in the tissue. Monocytes derive from bone marrow and circulate in the blood stream.

\section{LYMPHOCYTES}

Lymphocytes are the major component of chronic inflammation and play a major role in the immune response. ${ }^{24} 47$ There are two broad types of lymphocytes that are differentiated morphologically by their surface markers. ${ }^{47}$ $\mathrm{T}$ lymphocytes (CD3) are thymus derived and $\mathrm{B}$ lymphocytes (CD19) are bone marrow derived. T lymphocytes are important in the cellular immune response. $T$ lymphocytes are further divided into two main subtypes, T helper (CD4) and T suppressor/cytotoxic cells (CD8). Predominant T lymphocytic infiltration is commonly observed in viral infection and non-infectious inflammation. In eyes with sympathetic ophthalmia, CD4 cells are predominantly observed in the early stage and more CD8 cells are reported in the later stage of the disease. $^{48}$

We have reported predominant $\mathrm{T}$ lymphocytic infiltration in various non-infectious inflammatory diseases including ligneous conjunctivitis, ${ }^{49}$ idiopathic Mooren's and Terien's corneal degeneration, ${ }^{50}$ anterior uveitis, ${ }^{51}$ pars planitis, ${ }^{52}$ sarcoidosis, ${ }^{25}$ sympathetic ophthalmia, ${ }^{53}$ and VKH syndrome. ${ }^{54}$ The majority of T cellular infiltration is also documented in other uveitides in the literature, such as Behçet's disease ${ }^{55} 56$ and scleritis. Being the precursors of plasma cells, B lymphocytes are important in the humoral immune response. A relative increase of B lymphocytic infiltration is observed in multifocal choroiditis and subretinal fibrosis with uveitis. ${ }^{57}$ Forming lymphoid follicles, aggregates of B cells are seen at the end stage of sympathetic ophthalmia ${ }^{59}$ and VKH syndrome. ${ }^{5460} \mathrm{~B}$ lymphocytes invading the eyes predominantly are recorded in reactive lymphoid hyperplasia ${ }^{61}$ and primary intraocular B cell lymphoma, a CNS non-Hodgkin's lymphoma involving the eye. ${ }^{62} 63$ 


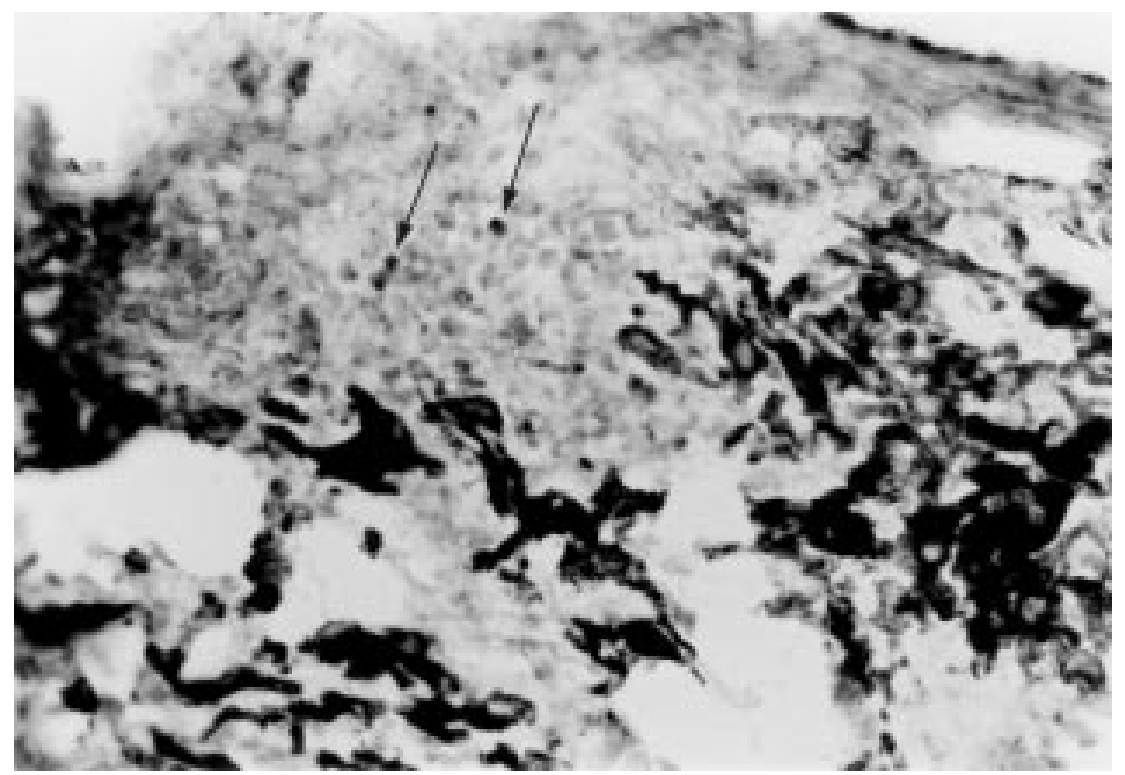

Figure 2 Microphotograph of the choroid from an eye with Behçet's disease shows positive IFN- $\gamma$ $m R N A$ (arrows) released by the infiltrating cells. The pigmented cells are the melanocytes in the choroid (in situ hybridisation, riboprobes-dioxygenin labelling, methyl green counterstain, $\times 280$ ).

CD4 $\mathrm{T}$ lymphocytes ( $\mathrm{Th}$ ) recognise antigens in association with MHC class II molecules. These cells help $\mathrm{B}$ cells produce antibody. These lymphocytes also release lymphokines that activate other cell types during the inflammatory process. Two distinct cytokine profiles are released by two CD4 subsets. Th1 cells produce IL-2, interferon $\gamma$ (IFN- $\gamma)$, and lymphotoxin whereas Th2 cells express IL-4, IL-5, IL-6, and IL-10. ${ }^{64}$ Both Th1 and Th2 cells are required for the induction and regulation of autoimmune diseases. In general, Th1 cells promote the development of the disease, whereas Th2 cells play a role in limiting the disease progress. Recently, Barton et al showed the kinetic changes of early expressions of IL-2, IFN- $\gamma$ (Th1 profile), and IL-4 mRNA, and then late expression of IL-10 mRNA (Th2 profile) in the retina during experimental autoimmune uveoretinitis. ${ }^{65}$ Numerous CD4 $\mathrm{T}$ cells and Th1 cytokine mRNAs are detected in eyes with active sympathetic ophthalmia (Fig 1) and Behçet's disease (Fig 2). This observation demonstrates that the infiltrating $\mathrm{T}$ lymphocytes have Th1 function and promote cellular immune response in the eye.

In the normal eye, there are no infiltrating inflammatory cells or their cytokines. Tissue macrophages are present in the uveal tissue.

\section{Ocular resident cells in uveitis}

Vascular endothelial cells, pigmented epithelial cells, corneal endothelial cells, and Müller cells are important ocular resident cells. Ocular resident cells respond to inflammation depending on the stimulus and the host condition. These cells alter their surface markers of MHC class I, class II, and adhesion molecules before inflammatory cells infiltrate the eyes. When bound to the antigenic peptides originating from within the cells, MHC molecules are recognised by $\mathrm{T}$ lymphocytes. The immune system will then switch on followed by the immune process. ${ }^{47}$ Expression of MHC class II markers on ocular resident cells has been found before the arrival of infiltrating leucocytes in eyes with various experimental uveitides. ${ }^{6-70}$ MHC class II molecules are upregulated by certain lymphokines including IFN- $\gamma$, which has been demonstrated in human eyes with inflammation. ${ }^{55}{ }^{56}$ Aberrant expression of MHC class II on non-haematopoietic cells induces a tolerogenic or anergising signal to autoreactive $\mathrm{T}$ cells. ${ }^{71}{ }^{72}$ Specific $\mathrm{T}$ cell activation requires complex costimulation, both receptor/ ligand interactions (CD 28/B7)and cytokine secretion (IL-1 $\beta$ and/or IL-6) which non-haematopoietic antigen presenting cells normally lack.

Adhesion molecules allow the migration of leucocytes to the site of inflammation. ${ }^{47}$ Expressions of adhesion molecules on ocular cells and the expression of the ligands (counterreceptors) on leucocytes suggest that their interaction is important in the development of uveitis. In various experimental uveitic models adhesion molecules on resident cells have been found before the infiltrating leucocytes have reached the inside of the eye..$^{69707374}$ Antibodies against adhesion molecules can suppress ocular inflammation in these animal models. ${ }^{73} 7576$ Expressions of adhesion molecules are also commonly found in uveitic eyes including sympathetic ophthalmia and ocular sarcoidosis. ${ }^{77}$

Apoptosis, a structurally distinct programmed cell death pathway without inflammation, is essential for the normal development and homeostasis of the immune system. The dysfunction of the apoptotic process may lead to autoimmunity or immunodeficiency. ${ }^{78}$ Numerous genes and their products have been defined to regulate apoptosis, whereas the complementary receptor pair, Fas (CD95) and Fas ligand (FasL), are particularly notable in immunoregulation. ${ }^{79}$ The induction of apoptosis by Fas-FasL interactions in the eye is a potent mechanism for the maintenance of immune privilege. ${ }^{80}$ Currently, an investigation of the role of apoptosis in uveitis is being conducted.

Ocular resident cells have also been suggested to have an immunosuppressive rather than an immunostimulatory activity ${ }^{81-85}$ The immunosuppressive properties of ocular resident cells are observed in human ocular tissues. Müller cells appear to be resistant to the inflammatory cell attack. They usually survive and may even proliferate to form a gliotic scar, particularly in the end stage of uveitis. ${ }^{53548}$ These observations appear to be in line with the in vitro studies showing that Müller cells not only inhibit the activated $\mathrm{T}$ lymphocytes but actually thrive on the soluble mediators they produce. ${ }^{81} 82$

\section{Conclusion}

The immunopathology of uveitis allows the visualisation of the morphological features at one precise instance in the 
changing dynamics of the inflammatory response in the eye. This information will help in making a clinical diagnosis and formulating a rational treatment plan. Immunopathology provides an excellent tool in our understanding of the pathogenesis of ocular inflammation which may reflect a spectrum of a similar pathological process. ${ }^{87}$

We thank Ms Dawn M Matteson and Mr Henry C Eng who provided editorial assistance.

\section{CHI-CHAO CHAN} QIAN LI

Section of Immunopathology, Laboratory of Immunology, National Eye Institute, Bethesda, Maryland, USA

Correspondence to: Chi-Chao Chan, MD, Building 10, Room 10N103, NIH/NEI, 10 Center Drive MSC 1858, Bethesda, MD 20892-1858, USA.

1 Valentino KL, Eberwine JH, Barchas JD. In situ hybridization applications to neurobiology. Oxford: Oxford University Press, 1987.

2 Nuovo GJ. PCR in situ hybridization: protocols and applications. 2nd ed. New York: Raven Press, 1994.

3 Beesley JE. Immunocytochemistry: a practical approach. 1st ed. Oxford: Oxford University Press, 1993.

4 Wick G, Traill KN, Schauenstein K. Immunofluorescence technology: selected theoretical and clinical aspects. $1 \mathrm{st}$ ed. Amsterdam: Elsevier Biomedical Press, 1982.

5 Wacker WB, Donoso LA, Kalsow CM, et al. Experimental allergic uveitis. Isolation, characterization and localization of a soluble uveitopathogenic antigen from bovine retina. F Immunol 1977;119:1949-58

6 Gery I, Wiggert B, Redmond TM, et al. Uveoretinitis and pinealitis induced by immunization with interphotoreceptor retinoid-binding protein. Invest Ophthalmol Vis Sci 1986;27:1296-300

7 Broekhuyse RM, Kuhlmann ED, Winkens HJ, et al. Experimental autoimmune anterior uveitis (EAAU), a new form of experimental uveitis. pigment epithelium. Exp Eye Res 1991;52:465-74.

8 Nussenblatt RB. Proctor lecture. Experimental autoimmune uveitis: mechanisms of disease and clinical therapeutic indications. Invest Ophthalmol Vis Sci 1991;32:3131-41.

9 La Hey E, Broersma L, van der Gaag R, et al. Does autoimmunity to $\mathrm{S}$-antigen play a role in Fuchs' heterochromic cyclitis? $\mathrm{Br} \mathcal{F}$ Ophthalmol 1993;77:436-9.

10 Forrester JV. Uveitis: pathogenesis. Lancet 1991;338:1498-501.

11 Nussenblatt RB, Gery I, Ballintine EJ. Cellular immune responsiveness of uveitis patients to retinal S-antigen. Am f Ophthalmol 1980;89:173-9.

12 Fukushima A, Lai JC, Chanaud NPr, et al. Permissive recognition of immunodominant determinants of the retinal S-antigen in different rat strains, primates and humans. Int Immunol 1997;9:169-77.

13 Gupta D, Singh VK, Rajasingh J, et al. Cellular immune responses of patients with juvenile chronic arthritis to retinal antigens and their synthetic peptides. Immunol Res 1996;15:74-83.

14 Chan CC, Palestine AG, Nussenblatt RB, et al. Anti-retinal auto-antibodies in Vogt-Koyanagi-Harada syndrome, Behçet's disease, and sympathetic ophthalmia. Ophthalmology 1985;92:1025-8.

15 Doekes G, Luyendijk L, Gerritsen MJ, et al. Anti-retinal S-antigen antibodies in human sera: a comparison of reactivity in ELISA with human or bovine S-antigen. Int Ophthalmol 1992;16:147-52.

16 Rao NA, Inomata H, Moorthy RS. Vogt-Koyanagi-Harada syndrome. In: Pepose JS, Hollan GN, Wilhelmus KR, eds. Ocular infection and inflammation. St Louis: Mosby, 1996:734-53.

17 .Matsuda H, Sugiura S. Utrastructural changes of the melanocyte in VogtKoyanagi-Harada syndrome and sympathetic ophthalmia. Fpn f Ophthalmol 1971;15:69-80.

18 Sakamoto T, Murata T, Inomato H. Class II major histocompatibility complex on melanocytes of Vogt-Koyanagi-Harada disease. Arch Ophthalmol 1991;109:1270-4.

19 Boisgerault F, Khalil I, Tieng V, et al. Definition of the HLA-A29 peptide ligand motif allows prediction of potential T-cell epitopes from the retinal soluble antigen, a candidate autoantigen in birdshot retinopathy. Proc Natl Acad Sci USA 1996;93:3466-70.

20 Folberg R. The eye. In: Spencer WB, ed. Ophthalmic pathology: an atlas and textbook. Chapter 1. Philadelphia: WB Saunders, 1996:1:1-37.

21 Howes EJ, Rao NA. Basic mechanisms in pathology. In: Spencer WB, ed. Ophthalmic pathology: an atlas and textbook. Chapter 13. Philadelphia: WB Saunders, 1996;4:2951-3010.

22 Hoefakker S, Boersma WJA, Claassen E. Detection of human cytokines in situ using antibody and probe based methods. If Immunol Meth 1995;185:149-75.

23 Chesselet MF. In situ hybridization histochemistry. Boca Raton, FL: CRC Press, 1990

24 Fantone JC, Ward PA. Inflammation. In: Rubin E, Farber J, eds. Pathology. Philadelphia: JB Lippincott, 1994:32-67.

25 Chan CC, Wetzig RP, Palestine AG, et al. Immunohistopathology of ocular sarcoidosis: report of a case and discussion of immunopathogenesis. Arch Ophthalmol 1987;105:1398-402.

26 Sabates R, Smith T, Apple D. Ocular histopathology in juvenile rheumatoid arthritis. Ann Ophthalmol 1979;11:733-7.

27 Eagle RCJ, Spencer WH. Lens. In: Spencer WB, ed. Ophthalmic pathology: an atlas and textbook. Chapter 5. Philadelphia: WB Saunders, 1996;1:42730.

28 Chan CC, Roberge FG. Sympathetic ophthalmia. In: Pepose JS, Holland $\mathrm{GN}$, Wilhelmus KR, eds. Ocular infection and immunity. Chapter 57. St Louis: Mosby, 1996:723-33.

29 Nussenblatt RB, Mittal KK, Ryan S, et al. Birdshot retinochoroidopathy associated with HLA-A29 antigen and immune responsiveness to retinal $\mathrm{S}$-antigen. Am f Ophthalmol 1982;94:147-58.
30 Green WR. The uveal tract. In: Spencer WH, ed. Ophthalmic pathology: an atlas and textbook. Chapter 10. Philadelphia: WB Saunders, 1996;3:18642099.

31 Pederson JE, Kenyon KR, Green WR, et al. Pathology of pars planitis. Am $\mathcal{F}$ Ophthalmol 1978;86:762-74.

32 Loewenfeld IE, Thompson HS. Fuchs' heterochromic cyclitis: a critical review of the literature. I Clinical characteristics of the syndrome. Surv Ophthalmol 1973;17:394-457.

33 Benestad HB, Laerum OD. The neutrophilic granulocyte. Curr Top Pathol 1989;79:7-36.

34 Barnathan ES, Raghunath PN, Tomaszewski JE, et al. Immunohistochemical localization of defensin in human coronary vessels. Am f Pathol 1997;150:1009-20.

35 Couto MA, Liu L, Lehrer RI, et al. Inhibition of intracellular Histoplasma capsulatum replication by murine macrophages that produce human defensin. Infect Immun 1994;62:2375-8.

36 Weller PF. The immunobiology of eosinophils. N Engl f Med 1991;374: $1110-8$.

37 Allansmith MR, Baird RS, Greiner JV. Vernal conjunctivitis and contact lens-associated giant papillary conjunctivitis: compared and contrast. $A m \mathcal{F}$ Ophthalmol 1979;87:544-55.

38 Chan CC, Li Q, Brezin AP, et al. Immunopathology of ocular onchocerciasis. 3 Th-2 helper T cells in the conjunctiva. Ocul Immunol Inflam 1992;1:

39 Galli SJ, Dvorak AM, Dvorak HF. Basophils and mast cells: morphologic insights into their biology, secretory patterns, and function. Prog Allergy 1984;34:1-84.

$40 \mathrm{Li} \mathrm{Q}$, Fujino Y, Caspi RR, et al. Association between mast cells and the development of experimental autoimmune uveitis indifferent rat strains. Clin Immunol Immunopathol 1992;65:294-9.

$41 \mathrm{Li} \mathrm{Q}$, Whitcup SM, Fujino Y, et al. The role of mast cells in endotoxin-induced uveitis. Invest Ophthalmol Vis Sci 1993;34:256-9.

42 Allansmith MR, Baird RS, Bloch KJ. Degranulation of ocular mast cells in rats undergoing systemic anaphylaxis. Invest Ophthalmol Vis Sci 1980;19: 1521-4.

$43 \mathrm{Li} \mathrm{Q}$, Luyo D, Hikita N, et al. Compound 48/80-induced conjunctivitis in the mouse: kinetics, susceptibility, and mechanism. Int Arch Allergy Immunol 1996;109:277-85.

44 Wakefield D, Li Q, McCluskey P, et al. Immunohistochemical localization of $T$ lymphocytes and macrophages and expression of interferon gamma and defensin in uveitis. Ocul Immunol Inflam 1994;2:153-9.

45 Chan C-C, BenEzra D, Hsu S-M, et al. Granulomas in sympathetic ophthalmia and sarcoidosis. Immunohistochemical study. Arch Ophthalmol 1985;103:198-202

46 Lewis CE, McGee OD. The natural immune system. The macrophage. Oxford: IRL Press, 1992.

47 Roitt I, Brostoff J, Male D. Immunology. 3rd ed. St Louis: Mosby, 1993.

48 Chan CC, BenEzra D, Rodrigues MM, et al. Immunohistochemistry and electron microscopy of choroidal infiltrates and Dalen-Fuchs nodules in sympathetic ophthalmia. Ophthalmology 1985;92:580-90.

49 Holland EJ, Chan CC, Kuwabara T, et al. Immunohistologic findings and results of treatment with CsA in ligneous conjunctivitis. Am $\mathcal{F}$ Ophthalmol 1989;107:160-6.

50 Lopez JS, Price FW, Whitcup SM, et al. Immunohistochemistry of Terrien's and Mooren's degeneration. Arch Ophthalmol 1991;109:988-92.

51 Stevens GJ, Chan CC, Wetzig RP, et al. Iris lymphocytic infiltration in patients with clinically quiescent uveitis. Am $\mathcal{F}$ Ophthalmol 1987;104:50815

52 Wetzig RP, Chan CC, Nussenblatt RB, et al. Clinical and immunopathological studies of pars planitis in a family. Br F Ophthalmol 1988;72:5-10.

53 Chan C-C, Nussenblatt RB, Fujikawa LS, et al. Sympathetic ophthalmia. Immunopathological findings. Ophthalmology 1986;93:690-5.

54 Chan CC, Palestine AG, Kuwabara T, Nussenblatt RB. Immunopathological study of Vogt-Koyanagi-Harada syndrome: report of a case. Am f Ophthalmol 1988;105:607-11.

55 Charteris DG, Barton K, McCartney ACE, et al. CD4+ lymphocyte involvement in ocular Behcet's disease. Autoimmunity 1992;12:201-6.

56 George RK, Chan CC, Whitcup SM, et al. Ocular immunopathology of Behçet's disease. Surv Ophthalmol 1997.

$57 \mathrm{Kim} \mathrm{M}$, Chan CC, Belfort RJ, et al. Histopathologic and immunohistochemical features of subretinal fibrosis and uveitis syndrome. $A m \mathcal{F}$ Ophthalmol 1987;104:15-23.

58 Palestine AG, Nussenblatt RB, Chan CC, et al. Histopathology of subretinal fibrosis with uveitis syndrome. Ophthalmology 1985;92:838-45.

59 Shah DN, Piacentini MA, Burnier MN, Jr, et al. Inflammatory cellular kinetics in sympathetic ophthalmia. A study of traumatized (exciting) eyes. Ocular Immunol Inflam 1993;1:255-62.

60 Inomata H, Sakamoto T. Immunohistochemical studies of Vogt-KoyanagiHarada disease with sunset sky fundus. Curr Eye Res 1990;9:35-40.

61 Cheung MK, Martin DF, Chan CC, et al. Reactive lymphoid hyperplasia: diagnosis by chorioretinal biopsy. Am f Ophthalmol 1994;118:457-62.

62 Lopez JS, Chan CC, Burnier M, et al. Immunohistochemistry findings in primary intraocular lymphoma. Am f Ophthalmol 1991;112:472-4.

63 Kaplan HJ, Meredith TA, Aaberg TM, et al. Reclassification of intraocular reticulum cell sarcoma (histiocytic lymphoma). Immunologic characterization of vitreous cells. Arch Ophthalmol 1980;78:707-10.

64 Mosmann TR, Schumacher JH, Street NF, et al. Diversity of cytokine synthesis and function of mouse CD4+ T cells. Immunol Rev 1991;123:20929.

65 Barton K, McLauchlan MT, Calder VL, et al. The kinetics of cytokine mRNA expression in the retina during experimental autoimmune uveoretinitis. Cell Immunol 1995;164:133-40.

66 Fujikawa LS, Chan CC, McAllister C, et al. Retinal vascular endothelium expresses fibronectin and class II histocompatibility complex antigens in experimental autoimmune uveitis. Cell Immunol 1987;98:139-50.

67 Chan CC, Hooks JJ, Nussenblatt RB, et al. Expression of Ia antigen on retinal pigment epithelium in experimental autoimmune uveoretinitis. Curr Eye Res 1986;5:325-30.

$68 \mathrm{Kim}$ MK, Chan CC, Nussenblatt RB, et al. Pharmacologic effects on the expression of class II histocompatibility antigen in experimental endotoxininduced uveitis. Clin Immunol Immunopathol 1987;45:70-7.

69 Chan C-C, Hikita N, Dastgheib K, et al. Experimental melanin-protein induced uveitis in the Lewis rat: immunopathological process. Ophthalmology 1994;101:1275-80. 
70 Kim MC, Kabeer NH, Tandhasetti MT, et al. Immunohistochemical studies on melanin associated antigen (MAA) induced experimental autoimmune on melanin associated antigen (MAA) induced experim
anterior uveitis (EAAU). Curr Eye Res 1995;14:703-10.

71 Staines NA, Harper N. Oral tolerance in the control of experimental models Staines NA, Harper N. Oral tolerance in the control of

72 Wildner G, Thurau SR, Kagnoff MF. Cross-reactivity between an HLA-B27-derived peptide and a retinal autoantigen peptide: a clue to major histocompatibility complex association with autoimmune disease. Eur f Immunol 1994;24:2579-85

73 Whitcup SM, DeBarge LR, Caspi RR, et al. Monoclonal antibodies against ICAM-1 (CD54) and LFA-1 (CD11a/CD18) inhibit experimental autoimmune uveitis. Clin Immunol Immunopathol 1993;67:143-50.

74 Whitcup SM, Wakefield $\mathrm{D}, \mathrm{Li} \mathrm{Q}$, et al. Endothelial leukocyte adhesion molecule-1 in endotoxin induced uveitis. Invest Ophthalmol Vis $\mathrm{Sci}$ 1992;33:2626-30.

75 Wetzig R, Hooks JJ, Percopo CM, et al. Anti-Ia antibody diminishes ocular inflammation in experimental autoimmune uveitis. Curr Eye Res 1988;7: inflamm.

76 Whitcup SM, DeBarge LR, Rosen $\mathrm{H}$, et al. Monoclonal antibody against CD11b/CD18 inhibits endotoxin-induced uveitis. Invest Ophthalmol Vis Sci 1993;34:673-81.

77 Whitcup SM, Chan CC, Li Q, et al. Expression of cell adhesion molecules in posterior uveitis. Arch Ophthalmol 1992;110:662-6.
78 Carson DA, Ribeiro JM. Apoptosis and disease. Lancet 1993;341:1251-4.

79 Lynch DH, Ramsdell F, Alderson MR. Fas and FasL in the homeostatic regulation of immune responses. Immunol Today 1995;16:569-74.

80 Griffith TS, Brunner T, Fletcher SM, et al. Fas ligand-induced apoptosis as a mechanism of immune privilege. Science 1995;270:1189-92.

81 Caspi RR, Roberge FG, Nussenblatt RB. Organ-resident, nonlymphoid cell suppress proliferation of autoimmune T lymphocytes. Science 1987;237: 1029-32.

82 Roberge FG, Caspi RR, Nussenblatt RB. Glial retinal Muller cells produce IL-1 activity and have a dual effect on autoimmune T-helper lymphocytes. Antigen presentation manifested after removal of suppressive activity. $\mathcal{F}$ Immunol 1988;140:2193-6.

83 Helbig H, Gurley RC, Palestine AG, et al. Dual effect of ciliary body cells on T lymphocyte proliferation. Eur F Immunol 1990;20:2457-63.

84 Hooper P, Bora NS, Kaplan HJ, et al. Inhibition of lymphocyte proliferation by resident ocular cells. Curr Eye Res 1991;10:363-72.

85 Kawashima H, Prasad SA, Gregerson DS. Corneal endothelial cells inhibit $\mathrm{T}$ cell proliferation by blocking IL-2 production. F Immunol 1994;153:

86 Nork TM, Ghobrial MW, Peyman GA, et al. Massive retinal gliosis. A reactive proliferation of Muller cells. Arch Ophthalmol 1986;104:1383-9.

87 BenEzra D, Forrester JV. Fundal white dots: the spectrum of a similar pathological process. Br f Ophthalmol 1995;79:856-60. 